\title{
Factors Influencing on the Debt Consistency in Ukraine
}

\author{
Maksym Antonov \\ $\mathrm{PhD}$, Department of Finance, Banking and Insurance, Sumy State University, Ukraine.
}

\begin{abstract}
In the article, the authors analyze the debt stability of the state with the help of factor models in order to ensure timely response to the effects of heterogeneous factors that form the stable or unstable state of the debt management system, and the need to study the tightness of the relationship between them.

The approach to determining the direction and modeling the impact on the debt sustainability of fundamental exogenous macroeconomic (demography and labor market, real sector, balance of payments) and financial groups of factors (capital flows, money market, banking system and access to financing) with the use of correlation tools is proposed.
\end{abstract}

Key words: debt sustainability, destabilization of the public finance system.

JEL Classification: H63.

(C) The Author, 2018. This article is published with open access at Sumy State University.

\section{Introduction}

Strengthening the imbalances of the system of public finances in different countries of the world, and especially Ukraine in post-crisis conditions, makes it particularly important to determine the key factors affecting the level of debt sustainability in order to ensure timely response to their manifestations. Management of these factors allows to neutralize the risks and threats of the loss of such stability, however, because of the complex nature of the concept of "debt stability of the state", the difficulties in its formalization require a well-balanced approach to study the tightness of the relationship between them.

\section{Literature review}

In general, the question of the formation and management of public debt is broadly covered in scientific sources. Starting with A. Smith, it was believed that the state can not manage the public debt qualitatively. By itself, it leads to the destruction of capital in the form of withdrawal of resources from the economy in the sphere of consumption.

The Ricardian Equivalence Concept, given the rational behavior of consumers, which increases current savings in anticipation of rising tax rates because of debt financing of budget expenditures, denies its stimulating and anti-cyclical role.

P. Leroy-Bol'de argued that public debt could be regarded as a service provided by the state on the part of the owners of capital to finance its needs.

Marx pointed out the need for a combination and complementary system of public debt and tax systems. K. Dietzel wrote about such a relationship between the limits of the tax burden and the debt burden, and the choice between debt and tax financing is the cornerstone of modern business finance, according to G. Rozen.

Describing the development of theories of public debt in the historical retrospect, it should be noted that until the twentieth century. in scientific circles the negative attitude to the deficit of the state budget and its debt coverage prevailed. Overcoming the consequences of the Great Depression in the United States led to the flowering of Keynesianism, which relied on the exclusive role of scarce funding in the state's financial policy. At the same time, J. M. Keynes emphasized that problems with solvency of the state arise out of exceeding the level of public debt of a certain level of national income.

On the contrary, the neo-classical theory of M. Friedman limits the role of the state only in the management of the monetary sphere, the neoliberal theory of F. Hayek denies the necessity of a deficit budget, while in the works of R. Masgrayev, F. Modigliani the negative influence of the growth of the state debt on the welfare of consumers is substantiated.

Instead, R. Barro points out the neutral effect of public debt on consumer welfare compared to taxes. The achievements of R. Barrot and his theoretical equation, known as the Barro-Ricardo equation, are based on other models of debt and debt management, budget financing, the Sarentha Wallace model, the Bruno-Fischer model, and others. 
A separate unit in the study of debt sustainability of the state is the study of foreign authors. From the point of view of the mechanisms of returning to the previous level of the net value of the state's property to GDP and the estimated value of public debt to GDP, the public finance system is considered by U. Buiter and O.-Zh. Blanchard.

F. Balassone and D. Franco, subject to the condition of maintaining the debt sustainability of the system of public finances, take restrictions on the growth of rates of taxes and fees.

Among the well-known fiscal theorists who justify the need to establish restrictions in the management of public debt, in the theory of public choice and neo-institutionalism, we can name J. Buchanan and G. Tullock. In their view, debt financing of public expenditures is an inalienable feature of the modern democratic process, and governments that have access to such funding, which by their nature are anti-cyclical taxes, have no incentives to increase the effectiveness of their use. Moreover, the activities of such governments require the establishment of fiscal constraints - the rules.

The generalization of modern approaches to the justification of the debt model of financing public expenditures makes it possible to group the main arguments in its favor in such areas as: the need to respect intergenerational equity and generational inheritance in view of the implementation of capital expenditures intended for future use in the current period; lack of private investment to ensure full employment and the need to attract financing for the deficit; necessity of financing anti-cyclical measures at the expense of equalization of the primary budget balance at the time of the surplus; development of the market of government securities as the basis of monetary and credit regulation of the economy.

In scientific sources polar approaches to the understanding of debt sustainability (debt sustainability) as a scientific concept were formed.

R. Neck and J. E. Storm indicate the need to fulfill two basic conditions for its achievement:

1) an interim budget constraint that requires government expenditures on current consumption and maintenance costs of current debt to be equal to tax revenues and the issuance of new debt (formula 1). It follows that governments can not play Ponzi in the long run.

$\mathrm{G}_{\mathrm{t}}+\left(1+\mathrm{i}_{\mathrm{t}}\right) \mathrm{B}_{\mathrm{t}-1}=\mathrm{T}_{\mathrm{t}}+\mathrm{B}_{\mathrm{t}}$

Where $G_{t}-$ government expenditures over time $t$;

$i_{t}$ - the interest rate on government securities within a single period of time;

$\mathrm{T}_{\mathrm{t}}-$ tax revenues for a specified period $t$;

$\mathrm{B}_{\mathrm{t}}$ - public debt is issued in the period of time $\mathrm{t}$.

2) reducing the share of government debt in GDP over a specified period to the established benchmark, which allows the government to be more flexible in responding to the impact of macroeconomic shocks.

A similar approach to the definition of debt sustainability is also found in the work of S. Kolignon, which indicates that the need to direct the current discounted debt value to zero is a key idea of all modern models of debt sustainability. This view is supported by A. Craidel.

According to Z. Veliyeva, debt sustainability characterizes such a debt policy that does not allow unrestricted increase in the ratio of public debt to GDP. In this context, I would like to note the general character of the quantified quantitative approach to understanding "debt sustainability" and its limited nature, because the definition of the critical level of the public debt quota in GDP for each state - that is, a certain limit - is the point of bifurcation of the debt sustainability of its public finance system In general, whether the debt management system requires, in particular, balanced and integrated approaches. In the work of C. Reinhart and K. Rogoff, evidence is provided that safe levels of debt for some countries may turn out to be critical to other countries. In addition, a large-scale analysis of these authors showed that in the period from 1970 to 2008 , the ratio of external debt to GNP exceeded $100 \%$ only in $16 \%$ of cases of default or restructuring, and more than half of defaults took place with the values of the indicator "external debt / GNP" which did not exceed $60 \%$.

However, the identified approaches to defining debt sustainability based on the "debt to GDP" indicator have long been the basis for its parametric description in academic circles, in Bon's works $(1998,2008)$ and its followers (for example, J. Luckesen and H. Rojaas-Romagos and relied on verification of this indicator for stationarity. 
In response to the growing problem of sovereign debt in the post-crisis period, a group of academics led by A. Goshe modified the threshold approach to defining debt sustainability, considering the concept of fiscal space, and laid the basis for defining two components: a stable and critical level of debt.

Under the notion of a stable level of debt (conditionally stable level), the authors understand the importance of debt in the long run until it has exceeded the level of maximum sustainable debt. This is the amount of debt that the country can serve over a fairly long period. It is necessary to have a margin of safety in order to withstand short-term increases in debt above this level. If the country's debt is lower than this level, the probability of default can be close to zero.

The critical level of debt (the highest level of debt) is the value of public debt, exceeding which is very likely to lead to a debt crisis.

The author's name stated that even the approach to this threshold of state debt should be avoided, since its equilibrium with values close to critical becomes vulnerable. Median estimates of threshold values for developed economies amounted to 50-75\% of GDP at long-term debt levels and 80-192\% of GDP at maximum sustainable, for developing countries $25 \%$ of GDP and $35-77 \%$ of GDP respectively.

In 2011, based on this work, the IMF prepared proposals for modifying the criteria for assessing debt sustainability "Modernizing the framework for fiscal policy and public. Debt sustainability analysis (DSA) 2011 "based on taking into account not only the level of public debt, but also the dynamics of its key factors: country specificity (basic conditions such as the primary budget balance, the level of interest rate, the rate of GDP growth); budgetary risks; risks related to the structure of debt; correlation of balance of public finances and public debt (it is planned to take into account indicators of state enterprises, projects of public-private partnership, pension programs and health programs).

Under this concept, a public debt can be considered sustainable if the primary budget balance allows it to be stabilized when implementing the most probable crisis scenarios for a specific economy. Marginal debt (current or expected government debt level for developing countries - 50\% of GDP, for developed countries $-60 \%$ of GDP, current or expected expenditure on servicing gross national debt -10 and $15 \%$ of GDP respectively) can be considered as indicators of need further analysis of debt sustainability risks within alternative scenarios.

Thus, the most complete, in our opinion, definition of "debt sustainability" is the definition contained in the IMF program documents that considers it as a situation in which the borrower is expected to be able to continue to serve its debts without unlikely significant future corrections in the balance of income and costs. A similar definition of debt sustainability is also contained in the IMF's State Debt Management Statistics Manual. In this case, the necessary and sufficient conditions for its availability are: the absence of expected debt restructuring and the minimum acceptable levels of macroeconomic, fiscal, etc. types of risks (vulnerabilities) associated with debt; elimination is possible.

The fundamental principles of debt sustainability management of the state were formed by R. Barro, O. Blanchard, L. Braginskaya, V. Vavilov, A. A. Ghosh, K. Debrun, L. Calmfors, JM Keynes, T. Kinda, M. Kumar, R. Musgrave, R. Neck J.-E. Storm.

\section{Methods and results}

The article uses the following methods of scientific research: correlation analysis - to analyze the direction of influence of factors on the level of debt stability of the state; methods of statistical analysis - for assessing the indicators of debt stability of the state; Shuhart maps and the Irwin method - to develop methodological tools for monitoring and forecasting debt sustainability of the state.

From the traditional analysis of key macroeconomic aggregates, existing approaches to studying debt-defining factors are now shifted towards analyzing macroeconomic shocks and risks - as partial manifestations of certain factors. Accordingly, the methods of analysis of debt sustainability from traditional factor (Table 1) are reorientated on stress testing methods, sensitivity estimation and scenario modeling. In this case, factor analysis does not lose its importance as the primary stage of its monitoring and assessment of sustainability through the simplicity of implementation and unambiguous interpretation.

An appropriate study of the EU's experience in constructing composite indicators of financial stability assessment S0, S1 and S2 is relevant in the context of the study of factors affecting Ukraine's debt sustainability and the implementation of the Association Agreement provisions. Among the most important 
factors that underlie S0 indicator stress tests, in addition to traditional factors that determine the dynamics of government revenues, expenditures, the primary surplus, demographic indicators, indicators of the real and financial sector should be called.

Table 1. Approaches to analyzing and modeling the level and state of public debt in scientific sources

\begin{tabular}{|c|c|c|}
\hline $\begin{array}{l}\text { Approach to constructing } \\
\text { a model }\end{array}$ & Factors & Results \\
\hline Econometric & $\begin{array}{l}\text { The pace of changes in the real Gross } \\
\text { Domestic Product, the exchange rate } \\
\text { of the hryvnia, the balance of } \\
\text { payments balance, the import / } \\
\text { export ratio, the cost of repayment of } \\
\text { the principal and interest on external } \\
\text { debt in relation to the volumes of } \\
\text { exports of goods and services. }\end{array}$ & $\begin{array}{l}\text { A quantitative assessment of government external debt by } \\
\text { type of instrument and debt owner and projected estimates of } \\
\text { volumes of foreign state and state-guaranteed debt } \\
\text { obligations have been made. }\end{array}$ \\
\hline $\begin{array}{l}\text { Distributive lagova and } \\
\text { autoregressive models }\end{array}$ & $\begin{array}{l}\text { Budget deficit, consumer price } \\
\text { index, Gross Domestic Product. }\end{array}$ & $\begin{array}{l}\text { Forecasting the level of external public debt, depending on } \\
\text { the level of macroeconomic indicators. }\end{array}$ \\
\hline Correlation model & $\begin{array}{l}\text { Government debt, Gross Domestic } \\
\text { Product. }\end{array}$ & $\begin{array}{l}\text { The close correlation between the dynamics of the state debt } \\
\text { and the gross domestic product in the conditions of the } \\
\text { transformational decline has been revealed and the } \\
\text { expediency of stimulating economic growth by increasing the } \\
\text { state loans is substantiated. }\end{array}$ \\
\hline $\begin{array}{l}\text { Trend models; multi- } \\
\text { factor regression analysis }\end{array}$ & $\begin{array}{l}\text { Revenues, expenditures of the state } \\
\text { budget, balance of payments } \\
\text { balance, gross domestic product } \\
\text { dynamics. }\end{array}$ & $\begin{array}{l}\text { It was found that the growth of the gross domestic product, } \\
\text { the reduction of the balance of payments, the increase of } \\
\text { expenditures on social security, the increase of capital } \\
\text { investments, the development of wholesale trade and the } \\
\text { reduction of capitalization and the index of consumer prices } \\
\text { lead to an increase in the state debt. }\end{array}$ \\
\hline $\begin{array}{l}\text { Early warning models } \\
\text { (probit / logit model, } \\
\text { signal indicators) }\end{array}$ & $\begin{array}{l}\text { Index of real wages, PFTS index, } \\
\text { industrial release, retail trade, } \\
\text { construction volumes, consumer } \\
\text { price index, producer price index, } \\
\text { real effective exchange rate, nominal } \\
\text { effective exchange rate J.P. Morgan }\end{array}$ & $\begin{array}{l}\text { An Early Warning System for Fiscal Impairment Factors } \\
\text { Finding is developed that allows us to find and evaluate the } \\
\text { risks of obtaining planned revenues from value added tax and } \\
\text { profit tax. }\end{array}$ \\
\hline
\end{tabular}

A separate direction in the factor analysis of debt sustainability is the assessment of the probability of occurrence of debt crises under the influence of macroeconomic factors and the development of early warning systems. Some developments in factor analysis are present in the methodological documents of interfilial turnover. According to World Bank experts, three groups of factors have a significant influence on the debt sustainability of the state: the accumulated amount of external debt and the conditions for its repayment; the dynamics of economic development of the country; dynamics, structure and conditions of refinancing of loans. At the same time, noting the concentration of these approaches on the factors that are conditioned by the functioning of the system of public debt management itself - its volume, structure, ratio with separate economic indicators does not fully take into account the influence of macroeconomic and financial variables, which illustrate the effect of the risk of loss of debt sustainability through external channels trade, the real sector, the financial sector, etc.

In order to overcome these shortcomings, avoid duplication and determine the impact of the most important external (exogenous) factors in relation to the system of public debt management, we will propose an author's methodology for their definition and modeling, which provides consideration of the fundamental exogenous macroeconomic and financial factors that determine the level of debt sustainability. Before moving on to their direct assessment, it is necessary to note the uniqueness of the situation in the system of managing its public debt: for the first time in the history of its independent existence, faced with a "closed circle" of factors and double deficits that have extremely threatening consequences and play a key role in deepening destabilizing public finances and economic recession. Thus, the level of debt sustainability in Ukraine in 2014-2015 was negatively affected by the coincidence of a number of endogenous and exogenous factors that show selfreinforcing trends and directly trigger a «debt-spiral» promotion - an increase in the budget deficit leads to an increase in debt, which in turn requires an increase state expenditures for its servicing. Among these factors are: the existence of a double-entry balance of payments - both on the account of current operations and on the account of the movement of capital and finance; the fall in the level of international reserves aimed at covering the balance of payments deficit directly generates additional devaluation and inflationary pressures 
and destructively affects the money market; the existence of a double deficit not only in the balance of payments, but also in the deficit of the state budget; formation of a devaluation-inflationary spiral: an increase in the level of inflation becomes the basis for the growth of the depreciation expectations of the population and further pressure on the exchange rate; the interconnected combination of inflation with the fall of industrial production. Particular attention should also be paid to exogenous factors of a qualitative nature, exacerbated by the influence of quantitative exogenous and endogenous factors.

Among the factors of a qualitative nature, which determine the debt stability of the state, in addition to political stability, transparency of government in general and public debt management system, in particular, the level of development of domestic borrowing markets, it is necessary to note the quality of their policies and institutions. The most important conclusion that follows from the analysis is the warning about the increasing likelihood of debt crises in countries with low institutional and institutional capacity.

Important factors in the qualitative impact on Ukraine's debt sustainability include the deterioration of access to international capital markets, the growth of capital outflow from the country as a result of its closure for foreign investors and a decrease in lending sovereign ratings to the pre-deflation level, which led to an increase in the cost of external borrowing and a narrowing of space for fiscal consolidation.

So, in December 2014, the rating agency Standard \& Poor's Ratings Services assigned an assessment of the long-term sovereign rating of Ukraine in foreign currency at the level of 'SSS-'. In February-March 2015, Fitch Ratings and Moody's Investors Service lowered Ukraine's foreign currency credit ratings to "CC' and "SA" levels with a negative outlook.

Particular attention should be paid to such a qualitative factor that caused the emergence of critical imbalances in the system of public debt management in Ukraine, as the impact of the global financial crisis in 2008-2010 intensified in the absence of a well-balanced strategy for borrowing and the implementation of the innovative and investment objective of their use.

Thus, in the context of the increase in the level of the budget deficit in 2008-2010, connected with the deployment of crisis measures, the recapitalization of troubled banks, in the absence of a clear strategy for the effective use of the resources involved in the modernization of the economy, consolidated public debt has doubled: from 20\% Gross Domestic the product (as of the end of 2008) to 40\% of the Gross Domestic Product (as of the end of 2010). The European developing countries, external borrowing to cover current deficits and consumption instead of structural reform of the economy, combined with weak fiscal discipline, ambiguous monetary policy has led to an unjustified increase in public debt and the cost of its servicing.

An effective feature that illustrates the level of debt sustainability, within our study, we suggest to consider its traditional indicator of the ratio of the amount of public debt to the gross domestic product. It is necessary to make certain reservations and arguments in favor of its use. Thus, the indicated indicator illustrates the ratio of the stock - the amount of public debt accumulated at a certain time, as well as the flow rate - created over certain periods of value added in all sectors of the economy (Gross Domestic Product), which can be interpreted as a methodological violation. In addition, the same values of the indicator for different countries can indicate a different state of debt stability, given the impact of a significant number of other factors (currency, time, interest structure of debt, for example). In favor of using it as an indicator of debt sustainability in this study, we consider it necessary to argue the following: the indicator illustrates the relation between the accumulated debt and the results of the functioning of the real economy sector, where sources are generated for repayment of this debt; characterizes the level of debt load (pressure) on the current and prospective state of the country's economy; integrates the impact of such macroeconomic variables as inflation and real interest rates, which allows taking into account the current situation in the system of public finance management and the size of real expenditures from the budget for debt financing; acts as a measure of the ability of the state to fulfill its debt obligations at the expense of the existing and potential potential of the economy to grow; has a simple and unambiguous interpretation and a settled approach to the calculation and allows comparisons of countries with different levels of economic development.

Proceeding from the fact that debt sustainability is a dynamic indicator, its level can be characterized by factors that are specified in a certain set of indicators, which is actually a quantitative assessment of the mechanism of their influence. The priority of the comparability of these indicators and the unity of the methodology in the development of the database for the study of Ukraine's debt sustainability led to the choice of indicators from the World economic outlook and World Development Indicators (World Development Indicators) indicators. The selected information base is given in appendix D. Among the procedures for the primary processing of 
these data, we can note the following: normalization of data based on computed descriptive statistics (averages, dispersions, mean square deviations); verification of factors of multi-caliber on the basis of construction of correlation matrices and exclusion from the regression equations of those variables, the correlation coefficient between which was more than 0.8 . On the basis of the selected factors, multi-factor regression models (Table 2) of the form were constructed: $\hat{y}=a_{0}+a_{1} x_{1}+a_{2} x_{2}+\ldots+a_{k} x_{k}$ where $a_{0}-a_{k}$-parameters of the equation; $x_{1}-x_{k}-$ independent variables.

Table 2. Influence of macroeconomic and financial factors on Ukraine's debt sustainability for the period of $1997-2015$

\begin{tabular}{|c|c|c|c|c|c|c|}
\hline 气े & Subgroup & Factor & Symbols & Model & $\begin{array}{c}\text { Determination } \\
\text { Coefficient, } \\
\text { R2 }\end{array}$ & $\begin{array}{l}\text { F- } \\
\text { Stats }\end{array}$ \\
\hline \multirow{8}{*}{ 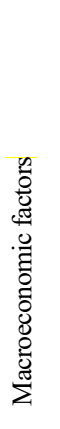 } & \multirow{2}{*}{$\begin{array}{l}\text { Demographics } \\
\text { and the labor } \\
\text { market }\end{array}$} & Population, mln. people & $\mathrm{P}$ & \multirow[b]{2}{*}{$\mathrm{Y}=11.24 \mathrm{U}-8.02 \mathrm{P}$} & \multirow[b]{2}{*}{0.87} & \multirow[b]{2}{*}{7.40} \\
\hline & & Unemployment rate, $\%$ & $\mathrm{U}$ & & & \\
\hline & \multirow[t]{3}{*}{ The real sector } & Total investments, $\%$ of GDP & TI & \multirow{3}{*}{$\mathrm{Y}=4.57 \mathrm{TI}+0.69 \mathrm{GNS}-0.24 \mathrm{I}$} & \multirow{3}{*}{0.88} & \multirow{3}{*}{5.12} \\
\hline & & Gross National Savings $\%$ of GDP & GNS & & & \\
\hline & & Inflation rate, $\%$ & I & & & \\
\hline & \multirow[t]{3}{*}{$\begin{array}{l}\text { Balance of } \\
\text { payments }\end{array}$} & $\begin{array}{l}\text { Real effective exchange rate } \\
(2010=100)\end{array}$ & $\operatorname{Rec}$ & \multirow{3}{*}{$\mathrm{Y}=-0.39 \mathrm{Rec}+1.01 \mathrm{CAB}+8.3 \mathrm{E}-10 \mathrm{TR}$} & \multirow{3}{*}{0.63} & \multirow{3}{*}{2.61} \\
\hline & & Balance of payments, $\%$ of GDP & $\mathrm{CAB}$ & & & \\
\hline & & $\begin{array}{l}\text { Total reserves (including gold), } \\
\text { USD USA }\end{array}$ & TR & & & \\
\hline \multirow{5}{*}{ 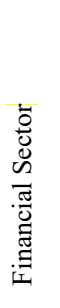 } & \multirow[t]{2}{*}{ Capital flows } & $\begin{array}{l}\text { Direct foreign investments on a } \\
\text { net basis, USD USA }\end{array}$ & FDI & \multirow{2}{*}{$\mathrm{Y}=5,16 \mathrm{E}-09 \mathrm{FDI}+6,29 \mathrm{E}-10 \mathrm{PI}$} & \multirow{2}{*}{0.70} & \multirow{2}{*}{8.29} \\
\hline & & $\begin{array}{l}\text { Portfolio foreign investments on a } \\
\text { net basis, USD, USA }\end{array}$ & PI & & & \\
\hline & \multirow{3}{*}{$\begin{array}{l}\text { Banking } \\
\text { system and } \\
\text { access to } \\
\text { financing }\end{array}$} & Share of problem loans in total, $\%$ & $\mathrm{BnL}$ & \multirow{3}{*}{$\mathrm{Y}=-0,32 \mathrm{BnL}-9,82 \mathrm{E}-10 \mathrm{CbL}+0,02 \mathrm{M} 2 / \mathrm{GDP}$} & \multirow{3}{*}{0.86} & \multirow{3}{*}{16.7} \\
\hline & & $\begin{array}{l}\text { Lending to banking institutions on } \\
\text { a net basis, USD, USA }\end{array}$ & $\mathrm{CbL}$ & & & \\
\hline & & Depth of financial sector,\% & M2/GDP & & & \\
\hline
\end{tabular}

Using the Scheme for interpreting the estimated values of determination coefficients $R_{2}$ for each of the models, we can state that there is a dense and very tight relationship $\left(0.6 \leq R_{2} \leq 0.9\right)$ between the investigated factors and Ukraine's debt sustainability.

We will comment on the results of the simulation. Keeping the overall division of the entire set of exogenous investigated in relation to the system of public debt management of macroeconomic and financial factors, we will analyze the constructed models by their subgroups.

Taking into account the constant reduction of the population of Ukraine, the increase in the level of mortality, retirement age and reduction of the general economic activity of citizens in the conditions of rising unemployment, caused by the general negative tendencies in the Ukrainian economy (the decline of industrial production), and the loss of economic potential of the occupied eastern regions, consolidated state budget through quasi-fiscal operations.

Such operations are aimed primarily at replenishing the Pension Fund deficit (UAH 19.0 billion in 2015), providing material assistance to internally displaced people from the Donbas, who lost their jobs, and increased payments for subsidies, etc. social assistance in conditions of impoverishment of the population and rising prices for communal services. Largely so-called Quasi-fiscal deficit was financed through T-bills - only in 2014 totaling over 205 billion UAH were placed (repaid - UAH 95 billion).

At the level of the constructed model, these trends are reflected in this way: the direct relationship between the population and the level of debt sustainability suggests that it decreases with the preservation of the tendencies towards the reduction of the number of able-bodied Ukrainians (the sign "+" near the independent variable P) and the inverse relationship between rising unemployment and lowering the level of debt sustainability (the sign "_" near the independent variable U). The Group of Factors "Real Sector" is characterized by a multidirectional impact on the level of debt sustainability in Ukraine. Unfortunately, the positive direct relationship between savings, investments and debt sustainability in Ukrainian realities for the analyzed period of 1997- 
2015 was unfortunately not implemented. The prevailing economic model in Ukraine is consumption-oriented rather than on the increase of innovative-investment potential at the expense of the balance of national savingsinvestments, as evidenced by the crisis of 2008-2010, which began with the segment of consumer banking lending and overheating of the economy at the expense of relatively cheap external borrowing from the banking and corporate sectors.

These factors are shown in Figure 1 have a direct impact on debt sustainability in recent years: the share of investments in the structure of the Gross Domestic Product in 2015 reached a critical level of $11.6 \%$, which indicates the destruction of the base to the potential recovery of the economy at the expense of its own sources and the deepening of dependence on external borrowing resources.

All available at the disposal of households and the public sector resources are directed not towards saving (9.9\% Gross Domestic Product in 2015), transforming then into investment, but on current consumption, which in 2014 reached more than $90 \%$ of Gross Domestic product.

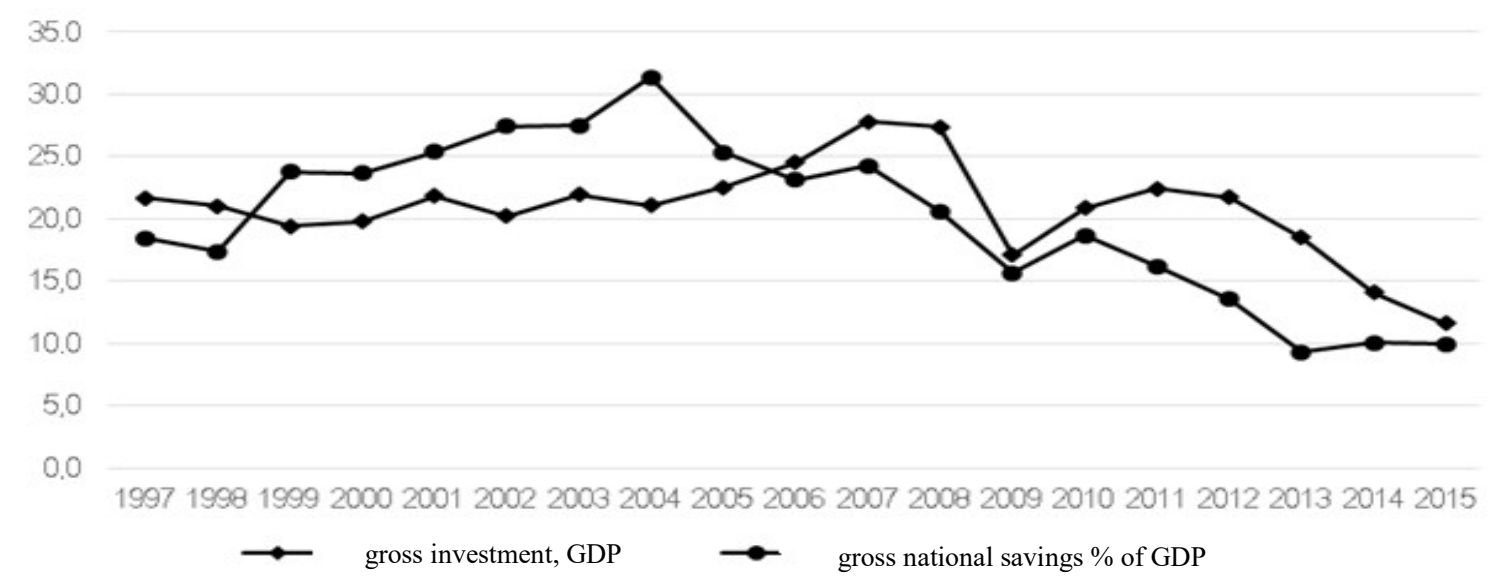

Figure 1. Dynamics of Total Investments and Gross National Savings in Ukraine in 1997-2015,\%, (World Economic Outlook Database)

The inverse relationship between the level of inflation (the official inflation index in 2014 increased by 24.9\%) and the level of debt sustainability of the state intensified in recent years due to a threefold devaluation of the hryvnia and a significant rise in the cost of housing and communal services by $34.3 \%$. A dangerous trend is the formation of not only the devaluation-inflationary spiral mentioned above, but also the mutual increase in inflation and the fall in production (14\%), which collectively led to a fall in the gross domestic product by $7 \%$ in 2014 (Figure 2).

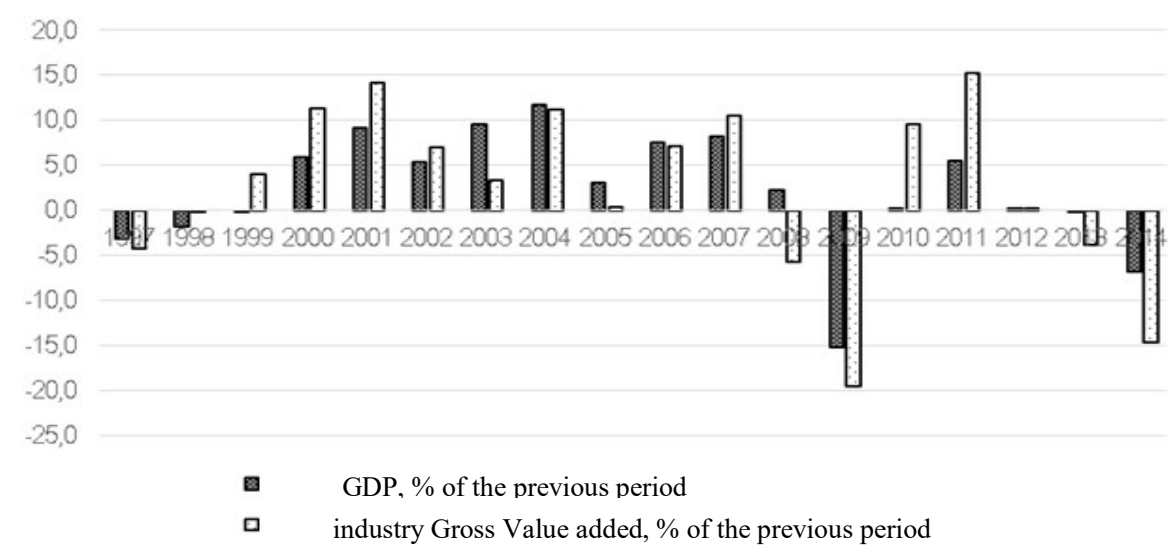

Figure 2. Dynamics of Gross Domestic Product and Gross Value Added in the Ukrainian Industry in 1997-2014,\% (World Economic Outlook Database)

Analyzing the Gross Domestic Product as the basis for determining the level of debt sustainability, it is worth emphasizing the negative trends that emerged in Ukraine GDP per capita GDP per capita in Ukraine during 2008-2013 fluctuated within the range of 8.3-8.6 thousand dollars. The US, however, already in 2014, it dropped to 8.2. Dollars USA, or to the level of 2007. These factors are an illustration of the deep economic crisis caused by the loss of a part of the industrial potential of the eastern regions in the conflict zone and economic ties with the Russian Federation as a result of the imposition of sanctions, which is embodied in the reduction of the Gross Domestic Product, the tax revenues to the revenue part of the budget in particular 
(income tax, VAT, and personal income tax) due to the growth of enterprises' losses ( $44 \%$ of enterprises from the total in 2014) and falling household incomes, declining debt sustainability and undermine the foundation for further growth.

Another double debt spiral characterizes the relationship between the balance of payments and the level of debt stability of the state. Despite the formal improvement of the balance of payments balance (the deficit in 2014 was USD 5 billion or $4.7 \%$ of gross domestic product) due to the devaluation of the hryvnia and the economic crisis, a double deficit in current operations and capital (due to deteriorating conditions external borrowing) exacerbates its negative impact on debt sustainability due to the chronic deficit of the state budget. The deepening of the state budget deficit is conditioned by the need to finance not only growing social payments in the context of the crisis, but also an increase in defense expenditures in a difficult military-political situation (by $84.4 \%$ in 2014), but also from financing from the state budget the deficit of NJSC Naftogaz of Ukraine (5.7\% of GDP in 2014 and its recapitalization in 2015 by UAH 29.7 billion).

Among the factors of the "Balance of Payments" group, the destructive effect on the level of debt sustainability should be called the three-fold devaluation of the national currency from 8 to 23-24 UAH per dollar), the fall in export earnings, the growth of negative expectations of households and the growth of demand for foreign currency. Such a significant devaluation under conditions of ineffective monetary policy of the NBU led to an increase in public debt (up $61.7 \%$ of its total volume at the end of 2014) and the cost of its servicing denominated in foreign currency (51.5\% in 2014), reaching one-third of the cost of the consolidated state budget), led to galloping inflation, falling welfare and purchasing power of the population and the formation of a threatening devaluation-inflationary spiral.

The negative balance of payments, the devaluation of the national and the state of the country's gold and currency reserves, the self-reinforcing effect of the debt spiral directly affect the level of debt stability of the state. By 2008, the volume of gold and foreign exchange reserves was sufficient to cover the government debt of Ukraine, which indicated an adequate level of debt sustainability. However, the recent reversal is unfolding (the level of international reserves in 2014 was reduced to USD 7.5 million), which exacerbates the course of the banking and currency crises in 2014-2015. We note only that the level of coverage of the total volume of direct the state and guaranteed by the state foreign debt to the foreign exchange reserves is ten times lower than during the crisis of 2008-2010 and amounted to only $19.4 \%$ at the beginning of 2015 , which could be the reason for the current account deficit (Fig. 3) insolvency of the state and is the basis for the announcement of technical default in 2015.

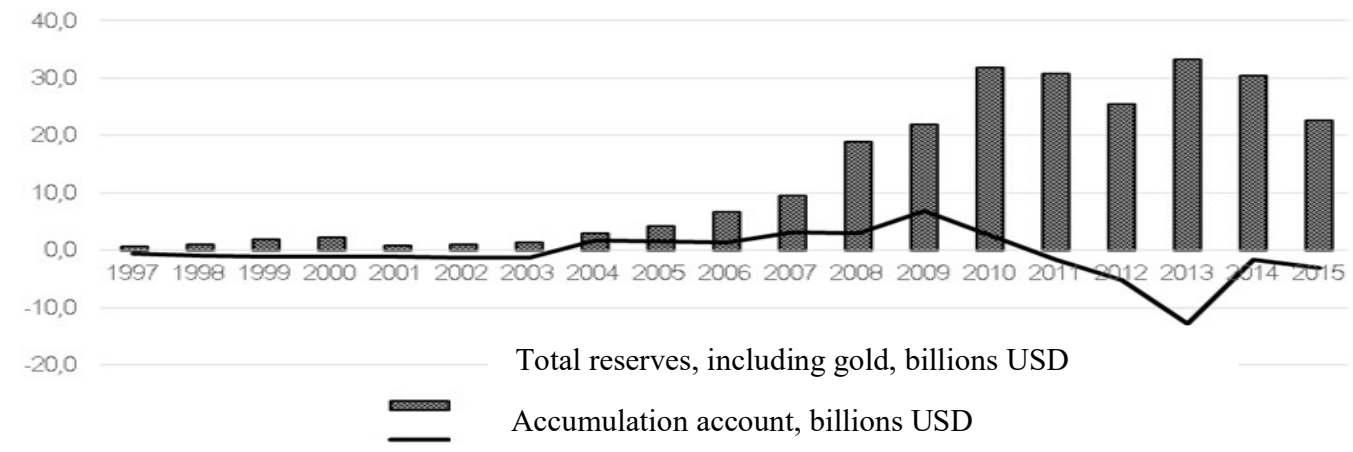

Figure 3. Dynamics of current account balance and general reserves of Ukraine in 1997-2015, billion dollars United States

Analyzing a group of financial factors, it is necessary to note their close, interconnected connection not only with the level of debt stability of the state, but also with the above considered macroeconomic factors. Direct and close links with the level of Ukraine's debt sustainability net flows of direct and portfolio investments are directly related to the balance of payments deficit - its dual nature results in an increase in external debt not compensated by either external investment or internal sources.

Negative dynamics of investment flows due to the deteriorating image of Ukraine, despite the August 2015 restructuring of the state debt means the need for new borrowings at higher rates and worse conditions that negatively affects Ukraine's debt sustainability in the future, which is explained by the effect of the "curve effect". In the conditions of the bank-centeredness of the financial system of Ukraine, the factors of the subgroup "Banking system and access to finance" show the high importance of the inverse (factors of the share of problem loans in the total volume, lending to banking institutions on a net basis) and direct (depth of the financial sector) influence on its debt sustainability. 
The growth of troubled customers' debts, the outflow of funds from the banking system (during 2014, customer revenues declined in the national currency by $13.4 \%$ (by UAH 56 billion), while in foreign (in dollar terms) by $36.8 \%$ (at 11 USD billion), the opaque policy of the NBU to refinance and recognize insolvent individual banks led to additional pressure on the state budget in terms of lending to both the banking institutions themselves and the Deposit Guarantee Fund, thus, in 2015, the amounts of such financing were respectively ban Institutions - UAH 36.5 billion, Individuals' Guarantee Fund - UAH 20 billion. Together with the decline of the financial sector (the deterioration of the development of the domestic financial market in general and the segment of government securities in particular) and the need to attract more expensive external resources, these factors have caused reducing Ukraine's debt sustainability through financial channels.

\section{Conclusion}

The negative impact of traditional factors related to incomes, expenditures and government budget deficits, currency, temporal structure of public debt coupled with analyzed and simulated macroeconomic and financial factors resulted in a low level of debt sustainability. These factors, taking into account the difficult geopolitical situation and the deep economic recession, in the absence of systemic and structural reforms and a wellbalanced public debt management strategy, increase the imbalances of public finances and the likelihood of default in Ukraine. Taking into account the importance of the analysis of the influence of these exogenous factors, the methodical tool for analyzing the influence of exogenous factors on the debt sustainability of the state, which, unlike existing ones, is based on the system of multifactorial regression models depending on the ratio of the volume of public debt to GDP from the totality of macroeconomic (demography and labor market, real sector, balance of payments) and financial groups of factors (capital flows, money market, banking system and access to finance).

This allowed for a comprehensive assessment of the cross-factor effects of debt-helixes: a "double deficit of the balance of payments - a deficit of the state budget", "international reserves - a devaluation and inflationary spiral", "inflation - the fall of industrial production and GDP".

\section{References}

1. Assessing Public Debt Sustainability in EU Member States. A Guide. Occasional Papers. Available at: http://ec.europa.eu/economy_finance/publications/occasional_paper/2014/op200_en.htm.

2. Balance of payments and international investment position manual. Available at: https://www.imf.org/external/pubs/ft/bop/2007/pdf/bpm6.pdf.

3. Baldacci E. Assessing Fiscal Stress Available at: https://www.imf.org/external/pubs/ft/ $\mathrm{wp} / . . . / \mathrm{wp} 11100 . \mathrm{pdf}$.

4. Ballassone F. (2000). Assessing Fiscal Sustainability: A Review of Methods with a View to EMU : Research Department, Fiscal Sustainability, 21-60.

5. Barnhill M.T. (2003). Assessting Fiscal Sustainability Under Uncertainty. IMF, 148.

6. Barro R. (1974). Are Govertment Bonds Net Wealth? Journal of Political Economy. 1097-1117.

7. Berg A. (1999). Predicting Currency Crises: The Indicators Approach and an Alternative. Journal of International Money and Finance, 18(4), 561-586.

8. Blanchard, O. (1990). The Sustainability of Fiscal Policy. New Answers to an Old Question. OECD Economic Studies., 15, 7-36

9. Buiter, W.A (1985). Guide to Public Sector Debt and Deficits. Economic Policy, 1, 13-79.

10. Calmfors L. Fiscal policy coordination in Europe. Available at: http://people.su.se/ calmf/FiscPolCoordEuropeFINAL.pdf.

11. Calmfors L. The role of independent fiscal policy institutions. Available at: http://su.divaportal.org/smash/get/diva2:388833/ FULLTEXT02.

12. Cassard M. Risk Management of Sovereign Assets and Liabilities. Available at: www.imf.org/external/pubs/ft/.../wp97166.pdf.

13. Debrun X. (2013). The Functions and Impact of Fiscal Councils. IMF, 62.

14. Debrun X. (2014). Strengthening Post-Crisis Fiscal Credibility: Fiscal Councils on the Rise - A New Dataset, 35.

15. Debt and (not much) deleveraging. February 2015 / Mckinsey \& company. Available at: http://www.mckinsey.com/insights/economic_studies/debt_and_not_much_deleveraging.

16. Debt Management Performance Assessment. Available at: http://www.worldbank.org/en/topic/ debt/brief/dempa-2015. 
17. Dietzel C. (1855). Das System der Staatsanleihen in Zusammenhang mit der Volkswirtschaft betrachtet. Berlin : Heidelberg,. 321.

18. Fiscal Monitor: Now Is the Time Fiscal Policies for Sustainable Growth. Available at: http://www.imf.org/external/pubs/ft/fm/2015/01/fmindex.htm.

19. Fiscal Sustainability Report. Available at: ISBN 978-92-79-22856-8.

20. Ghosh A.R. Fiscal fatigue, fiscal space and debt sustainability in advanced economies. Available at: http://www.nber.org/papers/w16782

21. .Giammarioli N. (2000). Assessing fiscal soundness: theory and practice. Occasional Paper Series No 56. ECB. Frankfurt am Main, 378.

22. World Bank Quarterly External Debt Statistics. Available at: http://databank.worldbank.org/ data/reports.aspx? source=quarterly-external-debt-statistics/sdds-(new).

23. World Bank. International Debt Statistics. Available at: http://data.worldbank.org/datacatalog/international-debt-statistics.

24. World Economic Outlook Database. Available at: http://www.imf.org/external/pubs/ft/weo/ 2014/02/weodata/index.aspx. 